\title{
SILICON ALUMINIUM ORDERING IN THE FRAMEWORK OF ZEOLITES
}

\author{
GLAUCO GOTTARDI and ALBERTO ALBERTI
}

\begin{abstract}
GOTTARDI, GLAUCO and ALBERTI, ALBERTO, 1985: Silicon aluminium ordering in the framework of zeolites. Bull. Geol. Soc. Finland 57, Part 1-2, 197-206.

The $(\mathrm{Si}, \mathrm{Al})$ ordering scheme in the framework of zeolites is reviewed, and four classes are recognized: 1 - zeolites with $\mathrm{Si}: \mathrm{Al}=1: 1$ and a simple order given by the alternation of $\mathrm{Si}$ and $\mathrm{Al} ; 2$ - zeolites with $\mathrm{Si}>\mathrm{Al}$ and an ordered distribution; 3 - zeolites with $\mathrm{Si}>\mathrm{Al}$ and partial Al-enrichment in some tetrahedra; 4 zeolites with $\mathrm{Si}>\mathrm{Al}$ and complete disorder, or at least with a framework that in principle favours disorder.

A crystallization model requiring the formation of cages of tetrahedra around a hydrated cation acting as a template is suitable for classes 3 and 4, but not for classes 1 and 2, which require the standard crystal growth scheme.
\end{abstract}

Key words: zeolite, framework, (Si, $\mathrm{Al})$ order, crystallization.

Glauco Gottardi and Alberto Alberti: Istituto di Mineralogia e Petrologia, Università di Modena, via S.Eufemia 19, 41100 Modena, Italy.

\section{Introduction}

The distribution of silicon and aluminium in the centre of the tetrahedra of framework silicates may be ordered or disordered, and every mineralogist knows how hard it is to solve the enigma of the real ( $\mathrm{Si}, \mathrm{Al})$ order in plagioclases, concealed in their modulated domain structure.

The (Si, $\mathrm{Al})$ distribution in the framework of zeolites has certainly not been the subject of investigations so detailed as those on feldspars: our paper therefore aims to give the present status of the subject matter for natural zeolites and to draw some conclusions on their crystallization.

From this particular point of view and without any other purpose, zeolites may be subdivided into four classes:
Class 1: Zeolites with $\mathrm{Si}:(\mathrm{Si}+\mathrm{Al}) \simeq 0.50$. These obey Loewenstein's rule and exhibit ordered distribution given by the alternation of $\mathrm{Si}$ and $\mathrm{Al}$ in the tetrahedra. An obvious consequence is that the rings with an odd number of tetrahedra are prohibited in their frameworks; ( $\mathrm{Si}, \mathrm{Al})$ disorder is possible only if $\mathrm{Si}:(\mathrm{Si}+\mathrm{Al})$ is slightly over $50 \%$.

Class 2: Zeolites with $\mathrm{Si}:(\mathrm{Si}+\mathrm{Al})>0.5$, which normally have nearly perfect ( $\mathrm{Si}, \mathrm{Al}$ ) order; disorder is possible but rare.

Class 3: Zeolites with $\mathrm{Si}:(\mathrm{Si}+\mathrm{Al})>0.5$ and a small but definite Al-enrichment repeatedly found in the same tetrahedra.

Class 4: Zeolites with any ratio $\mathrm{Si}$ : $(\mathrm{Si}+\mathrm{Al})$, in which disorder is highly favoured by their structural features, although order is possible, and has been detected clearly in some cases. 
The $\mathrm{Al}$ fraction in a tetrahedron is normally deduced from the average $\mathrm{T}-\mathrm{O}$ distance, for instance, using Jones' relation, 1968; here this relation will be used in a qualitative way only. We use $T$ as a code for both the tetrahedral node and the tetrahedron. Extraframework cations are normally located near the tetrahedra occupied by $\mathrm{Al}$ and hence with a deficit of positive charge. On the other hand, if a framework oxygen is at bond distance from an extraframework cation, its $\mathrm{T}-\mathrm{O}$ bond length is increased (see, for instance, Baur, 1978), but by such a small amount as to be negligible for the conclusions to be drawn in this article.

\section{Class 1}

This class contains only a few structurally well known species: gismondine, amicite, thomsonite and willhendersonite.

Gismondine (Fischer and Schramm 1971) and amicite (Alberti and Vezzalini 1979) share the same framework of tetragonal topological symmetry, and all tetrahedra are topologically equivalent, but the extraframework cations are positioned so as to reduce symmetry. The order is dominated by the $\mathrm{Al}-\mathrm{O}-\mathrm{Al}$ avoidance (Loewenstein's) rule: the presence of $\mathrm{Ca}$, which strongly favours order in many cases, is not decisive here, as the same order is also found in amicite too, which contains only $\mathrm{K}$ and $\mathrm{Na}$.

Thomsonite (Alberti et al. 1981) has a different framework but here, too, the order is simply imposed by Loewenstein's rule.

Willhendersonite (Peacor et al. 1984; Tillmanns and Fisher 1981) has a chabazite framework, and hence all tetrahedra are topologically equivalent. Nevertheless, Loewenstein's rule imposes ordered alternation of $\mathrm{Si}$ and $\mathrm{Al}$.

If the ratio $\mathrm{Si}:(\mathrm{Si}+\mathrm{Al})$ is slightly over $50 \%$ in one of these frameworks, the probability of antiphase domains grows rapidly. There are thus some thomsonites that are microcristalline and botryoidal and in which up to $55 \%$ of tetrahedra are occupied by Si. They feature Xray powder patterns with a weakening of all diffractions with 1 odd, clear evidence of disorder (Wise and Tschernich 1978). When describing the refinement of their thomsonite with Si: $(\mathrm{Si}+\mathrm{Al})=51 \%$, Alberti et al. (1981) showed that even with such a small increase in $\mathrm{Si}$, there is a slight tendency to disorder with a detectable increase of $\mathrm{Al}$ in one tetrahedron, which should be occupied by Si only. In other words, given an average $\mathrm{Al}$ decrease, the $\mathrm{Si}$ increase in the $\mathrm{Al}$ tetrahedra is larger than that strictly necessary to counterbalance the $\mathrm{Al}$ deficit, hence some $\mathrm{Al}$ is shifted to the Si-tetrahedra. This is a consequence of the »extended Loewenstein's rule»: if two nearby tetrahedra are both occupied by $\mathrm{Si}$, there is a greater likelihood of finding $\mathrm{Al}$ in the next tetrahedron.

Garronite has $\mathrm{Si}:(\mathrm{Si}+\mathrm{Al})=0.60$ and probably the same framework as gismondine. Its tetragonal space group gives some evidence for disordered zeolite, but the diffuseness of its Xray diffractions suggests the presence of ordered domains with four orientations (Gottardi and Alberti 1974).

There is no evidence of order in the X-ray powder patterns of chabazite, even if only $59 \%$ of the tetrahedra are occupied by Si (Passaglia, 1970). Unfortunately the samples are not suitable for single crystal work, which could provide better information.

\section{Class 2}

This class includes some fibrous zeolites plus laumontite, wairakite and yugawaralite.

Edingtonite: this zeolite may be orthorhombic (Galli 1976; Kvick and Smith 1983) or tetragonal (Mazzi et al. 1984). The average $\mathrm{T}-\mathrm{O}$ distances (see Table 1) show nearly perfect ( $\mathrm{Si}$, $\mathrm{Al}$ ) order in the orthorhombic mineral and complete disorder in the tetragonal one. There is no correspondence between the $\mathrm{Al}$ fraction in a tetrahedron and the vicinity of an extra- 
Table 1. Average $\mathrm{T}-\mathrm{O}$ distances $(\AA)$ in edingtonites.

\begin{tabular}{|c|c|c|c|c|c|}
\hline Sample & Symmetry & $\mathrm{T} 1-\mathrm{O}$ & $\mathrm{T} 2-\mathrm{O}$ & $\mathrm{T} 3-\mathrm{O}$ & Reference \\
\hline Böhlet Mine & orthorhombic & 1.609 & 1.623 & 1.752 & Galli (1976) \\
\hline New Brunswick & orthorhombic & 1.617 & 1.621 & 1.743 & Kvick and Smith (1983) \\
\hline Kilpatrick Hill & tetragonal & 1.660 & 1.666 & & Mazzi et al. (1984) \\
\hline Ice River & tetragonal & 1.658 & 1.668 & & Mazzi et al. (1984) \\
\hline
\end{tabular}

Note: in tetragonal edingtonites $\mathrm{T} 2$ is equivalent to $\mathrm{T} 3$.

framework cation barium; in fact $\mathrm{Ba}$ is linked to three framework oxygens, $\mathrm{O} 1, \mathrm{O} 2, \mathrm{O} 3$, all of which are vertices of both T2 (Al free) and T3 (Al filled).

Natrolite and tetranatrolite: although two names are used, the situation is similar to that of edingtonite; orthorhombic natrolite is a very common mineral and is usually perfectly ordered (see the first three samples in Table 2); as in edingtonite, there is no relation between the Al fraction in a tetrahedral node and the vicinity of an extraframework cation $\mathrm{Na}$ at bond distance from O2, O3, O4, all of which are vertices not only of site Al but also of Si2. The last two samples in Table 2 are partially disordered, and the existence of the tetragonal equivalent (KrogAndersen et al. 1969) termed tetranatrolite proves beyond doubt that complete ( $\mathrm{Si}, \mathrm{Al}$ ) disorder is also possible in this framework, even though this structure has never been refined because suitable crystals are not available. Tetranatrolite is much less common than orthorhombic natrolite, but it is still not a rare mineral.

Mesolite: Adiwidjaja (1972) found the following average $\mathrm{T}-\mathrm{O}$ distances for the tetrahedral nodes coded Si1 to Si5: 1.619, 1.620,

Table 2. Average T-O distances ( $\mathrm{A})$ in natrolites.

\begin{tabular}{lcccl}
\hline Sample & \multicolumn{3}{l}{ Sil-O Si2-O Al-O } & Reference \\
\hline Bergen Hill & 1.617 & 1.621 & 1.741 & Peacor (1973) \\
Techloviche & 1.622 & 1.617 & 1.746 & Pechar (1981) \\
Zalezly & 1.621 & 1.626 & 1.738 & Pechar et al. (1983) \\
Gulacs Hill & 1.627 & 1.631 & 1.729 & Alberti and \\
Zeilberg & 1.628 & 1.629 & 1.723 & Vezzalini (1981a) \\
\hline
\end{tabular}

$1.623,1.620 \AA$, and for the nodes coded Al1 to $\mathrm{Al} 3: 1.737,1.750,1.736 \AA$. It is obvious that there is nearly perfect $(\mathrm{Si}, \mathrm{Al})$ order. As in the other fibrous zeolites, no relation exists between the $\mathrm{Al}$ fraction in a node and the vicinity of an extraframework cation. Thus $\mathrm{Ca}$ is linked to O4, O6, O8, O11, which are part of the tetrahedra $\mathrm{Si} 2, \mathrm{Si} 3, \mathrm{Si} 4, \mathrm{Al} 1, \mathrm{Al} 2, \mathrm{Al} 3$, and $\mathrm{Na}$ is linked to O5, O7, O10, which are part of the tetrahedra $\mathrm{Si} 2, \mathrm{Si} 3, \mathrm{Al} 1, \mathrm{Al} 2$.

Scolecite: there are five non-equivalent tetrahedral nodes with the following $\mathrm{T}-\mathrm{O}$ distances (Smith et al. 1984): 1.616, 1.620, 1.620, 1.743, $1.749 \AA$. This means nearly perfect ( $\mathrm{Si}, \mathrm{Al})$ order. $\mathrm{Ca}$ is at bond distance from framework oxygens $\mathrm{O} 2, \mathrm{O} 3, \mathrm{O} 5, \mathrm{O} 6$, which are part not only of the tetrahedra Al1 and Al2 but also of $\mathrm{Si} 2$ and $\mathrm{Si} 3$.

Laumontite: according to Bartl (1970), there are three non-equivalent tetrahedral nodes. One is coded $\mathrm{Al}$ with an average $\mathrm{T}-\mathrm{O}$ distance of $1.750 \AA$; the other two are coded $\mathrm{Si} 1$ and $\mathrm{Si} 2$ with $\mathrm{T}-\mathrm{O}$ distances of 1.611 and $1.621 \AA$. Thus there is nearly perfect ( $\mathrm{Si}, \mathrm{Al})$ order. The extraframework cation $\mathrm{Ca}$ is at bond distance with $\mathrm{O} 2$ and $\mathrm{O} 3$, which are both part of the $\mathrm{Al}$ tetrahedron; the Sil and Si2 tetrahedra each contain one of these two oxygens.

Wairakite: Takeuchi et al. (1979) have shown that this species has a perfectly $(\mathrm{Si}, \mathrm{Al})$ ordered distribution, although its framework is the same as that of analcime, which is disordered or partially ordered. In wairakite, each $\mathrm{Ca}$ has two $\mathrm{Al}$ tetrahedra on two opposite sides, the other $\mathrm{Si}$ tetrahedra being a little farther away. 
Yugawaralite: Kerr and Williams (1969) found nearly perfect $(\mathrm{Si}, \mathrm{Al})$ order in its framework, with eight independent tetrahedral nodes: the first two, coded All and Al2, have average $\mathrm{T}-\mathrm{O}$ distances of 1.735 and $1.733 \AA$, the other six, coded Si1 to Si6, have 1.605, 1.613, 1.606, $1.612,1.603,1.612 \AA$. The only extraframework cation $\mathrm{Ca}$ is linked to framework oxygens $\mathrm{O} 3$, O7, O9, O12; Al1 and Al2 are each linked to two of these oxygens, whereas $\mathrm{Si} 2, \mathrm{Si} 3, \mathrm{Si} 4$ are each linked to one, and $\mathrm{Si1}, \mathrm{Si} 5, \mathrm{Si} 6$ to none.

\section{Class 3}

This class includes mordenite, dachiardite, epistilbite, ferrierite and bikitaite, all with similar frameworks, plus heulandite and brewsterite, again with similar frameworks, and finally mazzite, and perhaps offretite and levyne, all of which contain 6-rings in their structures.

The frameworks of the first four zeolites may be described as parallel nets with hexagonal meshes, connected by 4-rings (6-rings in ferrierite) normal to the plane of the nets.

Mordenite: in the Na-exhanged form, the data of Gramlich (1971) give very slight evidence for $\mathrm{Al}$ enrichment in $\mathrm{T} 3$ (a node in the 4-ring) because the distance T3-O (1.639 $\AA$ ) is slightly larger than the other three (1.625, $1.622,1.607 \AA)$. Moreover $\mathrm{O} 1$ and $\mathrm{O} 9$, all of which are part of tetrahedron T3, are coordinated by the extraframework cation, giving further support in favour of a higher Al fraction in T3. Note that two vertices of T3 are occupied by two symmetrically equivalent $\mathrm{O} 1$, which are also a vertex of T1. Mortier et al. $(1975,1976 a)$ have refined Ca-exchanged mordenites. In the dehydrated form $\mathrm{T} 3-\mathrm{O}$ is again larger $(1.63 \AA)$ than the others $(1.61,1.60$, $1.59 \AA$ ), and the oxygens $\mathrm{O} 1$ and $\mathrm{O} 9$ of this tetrahedron are coordinated by $\mathrm{Ca}$ I, the cation site with the highest ( $42 \%$ ) occupancy. The rehydrated form features once more the greatest $\mathrm{T}-\mathrm{O}$ distance (1.630 $\mathrm{A})$ for $\mathrm{T} 3$ comparable with
$1.621,1.615,1.604 \AA$ for the other tetrahedra. Hence, each of these three refinements gives such scanty evidence in favour of $\mathrm{Al}$ enrichment in T3 that some doubt could be cast on the significance of the information; however, all three investigations point in the same direction and this could not happen by chance. The $\mathrm{Al}$ fraction in T3 is probably ca. 20 or $25 \%$.

Dachiardite: Vezzalini (1984) refined its structure and coded T1 and T2 the tetrahedra nodes of the hexagonal nets, and T3 and T4, the nodes of the 4-rings. The $\mathrm{T}-\mathrm{O}$ distances are 1.648 and $1.623 \AA$ for $\mathrm{T} 3$ and $\mathrm{T} 4,1.612$ and $1.614 \AA$ for $\mathrm{T} 1$ and $\mathrm{T} 2$. The most occupied cation site is bound to $\mathrm{O} 1, \mathrm{O} 2$ and $\mathrm{O} 9$ : now, of these oxygens, $\mathrm{T} 1$ contains only $\mathrm{O} 1$ and $\mathrm{T} 2$ only $\mathrm{O} 2$, whereas $\mathrm{T} 3$ has two symmetrically equivalent $\mathrm{O} 1$ at its vertices, and $\mathrm{T} 4$ two symmetrically equivalent $\mathrm{O} 2$ plus one $\mathrm{O} 9$. So the highest $\mathrm{T}-\mathrm{O}$ distances certainly correspond to the highest $\mathrm{Al}$ fraction (ca. $30 \%$ ) of T4, one of the two nodes of the 4-ring. Also the other one, T3, is definitely higher in $\mathrm{Al}$ (ca. $20 \%$ ) than the nodes of the hexagonal net.

Epistilbite: Perrotta (1967) coded TA, the nodes of the 4-rings, TB and TC, being in the hexagonal nets. TA-O is $1.65 \AA$ as against 1.60 and $1.59 \AA$ for the other two. The extraframework cation site is at bond distance from $\mathrm{O} 1$ and $\mathrm{O} 3$, both of which are part of the TA tetrahedron; $\mathrm{O} 3$ is also a vertex of TC. The $\mathrm{Al}$ fraction in the nodes of the 4-ring should be ca. $35 \%$.

Ferrierite: in this mineral, 6-rings (instead of 4-rings) represent the connections between the nets with hexagonal meshes. There are four non-equivalent tetrahedral nodes, $\mathrm{T} 3$ and $\mathrm{T} 4$ forming the nets, and two $\mathrm{T} 1$ and four $\mathrm{T} 2$ the 6-rings. According to Vaughn (1966), the average $\mathrm{T} 2-\mathrm{O}$ distance $(1.626 \AA)$ is greater than the other three $(1.613,1.599,1.596 \AA)$; according to Alberti and Sabelli (oral communication) T2$\mathrm{O}=1.638 \AA$, the other three dimensions being $1.610,1.609,1.600 \AA$. In any case these data are sufficient to state that $\mathrm{Al}$ is enriched in $\mathrm{T} 2$, that 
is, in the 6-rings and not in the nets. In this particular case the oxygens of the T2 tetrahedron are not linked to extraframework cations, because $\mathrm{Mg}$ is fully surrounded by water molecules only, and the other cation sites, occupied mainly by $\mathrm{Na}$ and $\mathrm{K}$, are too far from the $\mathrm{T} 2$ tetrahedron.

Bikitaite: this zeolite also contains parallel nets with hexagonal meshes, which, however, are connected by chains similar to those of pyroxenes. Kocman et al. (1974) coded T1 and T3 the nodes in the hexagonal nets, and T2, the nodes of the chains. The average $\mathrm{T}-\mathrm{O}$ distances are $1.681 \AA$ for the first two, and $1.610 \AA$ for the $\mathrm{T} 2$ of the chains. These values differ so much that they prove a $50 \% \mathrm{Al}$ fraction in the nets and nearly zero $\mathrm{Al}$ in the chains. What is more, the extraframework cation $\mathrm{Li}$ coordinates $\mathrm{O} 1$, $\mathrm{O} 2$ and $\mathrm{O} 6$, all vanrtices of the $\mathrm{T} 1$ and $\mathrm{T} 3$ tetrahedra, but not of the T2 tetrahedron.

Heulandite: this framework, which can be considered as an assemblage of units called 4-4 $-1-1$ or heulandite units, is topologically monoclinic with five non-equivalent tetrahedral nodes. Table 3 lists the average $\mathrm{T}-\mathrm{O}$ distances in nine minerals with this framework; five are $\mathrm{Si}$-poor and all show definite $\mathrm{Al}$ enrichment in $\mathrm{T} 2$, in good agreement with the fact that three of its vertices $(\mathrm{O} 1, \mathrm{O} 2, \mathrm{O} 10)$ are bound to the two main cation sites coded $\mathrm{C} 1$ and $\mathrm{C} 2$, or $\mathrm{M} 1$ and M2, and so on. T2 should contain ca. $40 \%$ of the $\mathrm{Al}$ in these five samples. Four samples (clinoptilolites) are Si-rich, and all show smaller
$\mathrm{T}-\mathrm{O}$ distances, although the $\mathrm{T} 2$ tetrahedron remains the largest and the $\mathrm{T} 1$ tetrahedron shows only limited shrinkage, probably because clinoptilolites have another important cation site (M3 of Koyama and Takeuchi 1977) at bond distance from O2, O3, O4, all vertices of $\mathrm{T} 1$.

Brewsterite: this framework too can be assembled connecting the heulandite units. There are four topologically different tetrahedral nodes, coded TA, TB, TC and TD by Perrotta and Smith (1964). The first three show $\mathrm{T}-\mathrm{O}$ average distances of $1.66,1.66,1.67 \AA$, whereas for TD the value is $1.58 \AA$. Schlenker et al. (1977) confirmed these data, giving 1.645, 1.664, 1.660 for the first three and $1.607 \AA$ for the fourth tetrahedron. Hence all the $\mathrm{Al}$ is present in the first three tetrahedra; evidence for the validity of this assertion is given by the coordination around $\mathrm{Sr}$, the only extraframework cation that includes $\mathrm{O} 1$ and $\mathrm{O} 2$, which are vertices of the first three tetrahedra but not of the fourth tetrahedron.

Offretite: there are two kinds of tetrahedral node in the framework: T1 in the double 6-rings and $\mathrm{T} 2$ in the simple 6-rings. The $\mathrm{T}-\mathrm{O}$ distance is $1.66 \AA$ for $\mathrm{T} 1$ and $1.62 \AA$ for $\mathrm{T} 2$ (Gard and Tait 1972). Nearly all the $\mathrm{Al}$ is therefore present in the double rings, even more so considering that $\mathrm{K}$, the only cation linked to framework oxygens, is bound to $\mathrm{O} 2$ and $\mathrm{O} 3$, both part of the double rings. On the other hand, the refinement performed on dehydrated natural offretite

Table 3. Average $\mathrm{T}-\mathrm{O}$ distances $(\AA)$ in heulandites and clinoptilolites refined in space group $\mathrm{C} 2 / \mathrm{m}$.

\begin{tabular}{lccccccl}
\hline Sample & Si: $(\mathrm{Si}+\mathrm{Al})$ & $\mathrm{T} 1-\mathrm{O}$ & $\mathrm{T} 2-\mathrm{O}$ & $\mathrm{T} 3-\mathrm{O}$ & $\mathrm{T} 4-\mathrm{O}$ & $\mathrm{T} 5-\mathrm{O}$ & Reference \\
\hline Nadap & 0.74 & 1.635 & 1.658 & 1.624 & 1.629 & 1.637 & Alberti and Vezzalini (1983) \\
Faroes & 0.75 & 1.630 & 1.658 & 1.640 & 1.615 & 1.635 & Alberti (1972) \\
Iceland & 0.75 & 1.633 & 1.655 & 1.637 & 1.629 & 1.654 & Bartl (1973) \\
Mossyrock Dam & 0.75 & 1.631 & 1.657 & 1.628 & 1.619 & 1.640 & Galli et al. (1983) \\
Azerbaijan & 0.79 & 1.624 & 1.658 & 1.630 & 1.620 & 1.628 & Bresciani-Pahor et al. (1980) \\
Siusi & 0.81 & 1.612 & 1.667 & 1.617 & 1.615 & 1.615 & Alberti (1975) \\
Kuruma Pass & 0.81 & 1.627 & 1.659 & 1.610 & 1.606 & 1.618 & Koyama and Takeuchi (1977) \\
Agoura & 0.83 & 1.625 & 1.645 & 1.612 & 1.607 & 1.615 & Alberti (1975) \\
Agoura & 0.83 & 1.624 & 1.645 & 1.618 & 1.615 & 1.614 & Koyama and Takeuchi (1977) \\
\hline
\end{tabular}


(Mortier et al. 1976b) gives nearly equal values (1.632 and 1.629A) for the two tetrahedra, and hence ( $\mathrm{Si}, \mathrm{Al}$ ) disorder may also be possible in offretite.

Levyne: There are again two kinds of tetrahedral node, which may be part of double (T1) and single (T2) 6-rings. The $\mathrm{T} 1-\mathrm{O}$ distance is slightly greater $(1.66 \AA)$ than the $\mathrm{T} 2-\mathrm{O}$ one

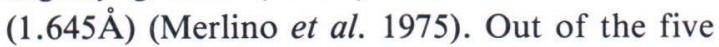
extraframework cation sites, only $\mathrm{C} 1$ has a high occupancy $(100 \%)$ and is at bond distance from $\mathrm{O} 2$, a vertex of $\mathrm{T} 1$. So actually one cannot exclude a small $\mathrm{Al}$ enrichment in $\mathrm{T} 1$, even though evidence thereof is sparse (levyne, like erionite, could also be placed in class 4 ).

Mazzite: two kinds of tetrahedral node are also present in this framework: T1 in the 6-rings and $\mathrm{T} 2$ in the walls of the gmelinite cages, with $\mathrm{T} 1-\mathrm{O}=1.653 \AA$ and $\mathrm{T} 2-\mathrm{O}=1.639 \AA \quad$ (Galli 1975). Alberti and Vezzalini (1981b) were able to give some evidence, based on crystal energy calculations, showing that the small $(0.014 \AA)$ difference in bond lengths is significant and that there is more $\mathrm{Al}$ in $\mathrm{Tl}(33 \%)$ than in $\mathrm{T} 2(24 \%)$.

\section{Class 4}

Typical representatives of class 4 are those zeolites whose tetrahedra are all topologically equivalent: a tendency to $(\mathrm{Si}, \mathrm{Al})$ disorder is foreseeable and could be counteracted either by a $\mathrm{Si}: \mathrm{Al}=1: 1$ ratio or by the presence of a divalent medium-sized cation such as $\mathrm{Ca}$. Typical examples are gmelinite, chabazite, faujasite, merlinoite and analcime.

Gmelinite: Galli et al. (1982) did not find any deviation from the maximum possible symmetry, which means that perfect $(\mathrm{Si}, \mathrm{Al})$ disorder only can be deduced from their refinement. On the other hand, the fact that sodium is the common extraframework cation does not favour order.

Chabazite: most of the refinements for this zeolite, with $\mathrm{Si}$ : $(\mathrm{Si}+\mathrm{Al})$ usually ca. $66 \%$, (see
Alberti et al. 1982, and quoted references) have been performed with the maximum symmetry allowed by the framework, and hence with only one kind of tetrahedron and without hope of finding any order. This simple situation is certainly not valid when $\mathrm{Si}$ : $(\mathrm{Si}+\mathrm{Al})$ is lowered to $50 \%$ as in willhendersonite, which exhibits perfect order (see class 1), and probably also not in many of the chabazites that show a symmetry lower than trigonal not only in optics (Majer 1953; Gottardi, 1978; Akizuki 1980, 1981) but also in structure (Mazzi and Galli 1983). These latter authors were able to demonstrate significant deviations in the tetrahedra dimensions from the average values when the symmetry was lowered from trigonal to triclinic. This partial ( $\mathrm{Si}, \mathrm{Al}$ ) ordering in a framework in which the tetrahedra are in principle equivalent, is certainly related to the presence (in the mineral and in the solution from which it crystallized) of calcium, which, being divalent and medium-sized, strongly favours order.

Faujasite: all the refinements for this cubic zeolite were carried out in space group $\mathrm{Fd} 3 \mathrm{~m}$, with only one independent tetrahedron, so that no deviation from disorder was detectable (Baur 1964; Bennett and Smith 1968).

Merlinoite: the framework of this zeolite, which is topologically tetragonal but really orthorhombic, contains two $\mathrm{T}-\mathrm{O}$ distances, 1.64 and $1.65 \AA$ (Galli et al. 1979); hence no order is present. In agreement with this disorder, oxygens of the two tetrahedra are equally bound to extraframework cations.

Analcime: analcime may be cubic and, if so, all tetrahedra are symmetrically equivalent and hence exhibit perfect ( $\mathrm{Si}, \mathrm{Al}$ ) disorder; the mineral can also be tetragonal, orthorhombic (Mazzi and Galli 1978) or even monoclinic (Hazen and Finger 1979). Schematically, the orthorhombic analcime has three non-equivalent tetrahedral nodes, each with a particular Al fraction; in the tetragonal analcime two of these three are equivalent and have the same $\mathrm{Al}$ fraction. The $\mathrm{Al}$ enrichment is always associated 
with a corresponding location of the extraframework cations, $\mathrm{Na}$, which have some freedom of choice, because there are only $16 \mathrm{Na}$ in a site of multiplicity 24 . With its perfectly ordered $(\mathrm{Si}, \mathrm{Al})$ distribution, wairakite is inserted in class 2.

Other zeolites, e.g. erionite, phillipsite, harmotome, stilbite, stellerite and barrerite, are known to have fully disordered ( $\mathrm{Si}, \mathrm{Al})$ distribution yet two or more topologically non-equivalent tetrahedra.

Erionite: like offretite, it contains double and single 6-rings (Kawahara and Curien 1969; Gard and Tait 1973), and hence tetrahedra of two kinds but with the same dimensions and both containing $\mathrm{O} 1$ and $\mathrm{O} 2$, the framework oxygens linked to the extraframework cation.

Phillipsite and harmotome: here we have only two topologically non-equivalent tetrahedra, but in the real monoclinic structure (Rinaldi et al., 1974), there are four non-equivalent tetrahedral nodes with average $\mathrm{T}-\mathrm{O}$ distances (in increasing order) of $1.651,1.654,1.655,1.664 \AA$; every tetrahedron contains two or three oxygens at bond distance from the extraframework cations. So there is not even the slightest evidence for order, which is consistent with the even distribution of the positive charges in the extraframework space.

Stilbite, stellerite and barrerite: Table 4 gives the average $\mathrm{T}-\mathrm{O}$ distances in these zeolites, all with the same framework. No ( $\mathrm{Si}, \mathrm{Al})$ order is apparent in their framework, in compliance with the fact that the main extraframework cation, $\mathrm{Ca}$, is fully surrounded by water molecules and not in contact with framework oxygens. The other cation, $\mathrm{Na}$, is monovalent and dispersed in many sites with low occupancy.

\section{Conclusions}

The $(\mathrm{Si}, \mathrm{Al})$ distribution in the tetrahedral framework of zeolites may be mainly ordered, as in our classes 1 and 2, or mainly disordered (with some partial enrichment in some tetrahedra), as in our classes 3 and 4 .

According to a generally accepted model (see for instance Breck 1974, p. 340), during a crystallization of a zeolite from an alumino-silicate (true or colloidal) solution, rings or cages of tetrahedra are formed around a hydrated cation. This acts as a template, and so the newly formed cage tends to a definite, constant shape. Subsequently this fragment sticks to the growing crystals, partly changing its arrangement to fit the structure better if necessary. In our opinion, this particular model of crystal growth may be applied only to zeolites of classes 3 and 4, in which the order is either absent or present in a partial, statistical way; any partial order is always related to the location of the extraframework cations as required by the model. In one special case (analcime-wairakite), any situation from perfect disorder to perfect order is possible. One disturbing case is that of ferrierite, which displays some partial order in its framework, even though no extraframework cation is in contact with framework oxygens. Stilbite reveals a similar situation but is fully

Table 4. Average T-O distances ( $\mathrm{A})$ in stilbite, stellerite and barrerite.

\begin{tabular}{lllllll}
\hline Mineral & Sil-O & Si2-O & Si3-O & Si4-O & Si5-O & Reference \\
\hline Stilbite, Iceland & 1.648 & 1.638 & 1.645 & 1.640 & 1.630 & Galli (1971) \\
Stilbite, Nova Scotia & 1.652 & 1.640 & 1.645 & 1.636 & 1.638 & Slaughter (1970) \\
Stellerite, Sardinia & 1.630 & & 1.640 & 1.630 & 1.640 & Galli and Alberti (1975a) \\
Barrerite, Sardinia & 1.637 & & 1.638 & 1.625 & 1.630 & Galli and Alberti (1975b) \\
\hline
\end{tabular}

Note: Si1 and Si2 are symmetrically equivalent in stellerite; for barrerite, the value given for Si1 is the average of Si1 and $\mathrm{Si} 1 \mathrm{P}$, which together are equivalent to $\mathrm{Si} 1$ and $\mathrm{Si} 2$ of stilbite. 
disordered; hence a certain tendency towards order is probably inherent in the structure type.

The template model cannot however be applied to the ordered zeolites of classes 1 and 2 . During their growth, the parts added to the crystai surface are single ions or anionic groups such as $\mathrm{AlO}_{4}$ and $\mathrm{SiO}_{4}$, but not larger clusters. In other words they grow like normal crystals, the type of the new linked atom ( $\mathrm{Si}$ or $\mathrm{Al}$ ) depending only on the crystal structure already grown, and not on the »structure» of the solution (lato sensu).

In class 1 the choice between $\mathrm{Si}$ and $\mathrm{Al}$ is imposed by Loewenstein's rule, in class 2 probably by the »extended Loewenstein's rule» (Merlino,

\section{References}

Adiwidjaja, G., 1972. Strukturbeziehungen in der Natrolithgruppe und das Entwässerungsverhalten des Skolezits. Diss. Univ. Hamburg.

Akizuki, M., 1980. Origin of optical variation in analcime and chabazite. Proc. Fifth Int. Conf. Zeolites (Rees L.V.C. ed.), Heyden, London, 171-178.

Akizuki, M., 1981. Origin of optical variation in chabazite. Lithos 14, 17-21.

Alberti, A., 1972. On the crystal structure of the zeolite heulandite. Tscherm. Miner. Petr. Mitt. 18, 129-146.

Alberti, A., 1975. The crystal structure of two clinoptilolites. Tscherm. Miner. Petr. Mitt. 22, 25-37.

Alberti, A. \& Vezzalini, G., 1979. The crystal structure of amicite, a zeolite. Acta Cryst. B35, 2866-2869.

Alberti, A. \& Vezzalini, G., 1981a. A partially disordered natrolite: relationships between cell parameters and Si-Al distribution. Acta Cryst. B37, 781-788.

Alberti, A. \& Vezzalini, G., 1981b. Crystal energies and coordination of ions in partially occupied sites: dehydrated mazzite. Bull. Miner. 104, 5-9.

Alberti, A. \& Vezzalini, G., 1983. The thermal behaviour of heulandites: structural study of the dehydration of Nadap heulandite. Tscherm. Miner. Petr. Mitt. 31, 259 -270 .

Alberti, A.; Vezzalini, G. \& Tazzoli, V., 1981. Thomsonite: a detailed refinement with cross checking by crystal energy calculations. Zeolites 1, 91-97.

Alberti, A.; Galli, E.; Vezzalini, G.; Passaglia, E. \& Zanaz$z i, P$. F., 1982. Positions of cations and water molecules
1984): if $\mathrm{Si}:(\mathrm{Si}+\mathrm{Al})>0.5, \mathrm{Al}$ must be distributed so as to minimize $\mathrm{Al}-\mathrm{O}-\mathrm{Si}-\mathrm{O}-\mathrm{Al}$ linkages. Such a rule may have importance only if the ratio $\mathrm{Si}:(\mathrm{Si}+\mathrm{Al})$ is low; this is true for zeolites of class 2 . The value of ratio is $60 \%$ in natrolite, mesolite and scolecite; $66 \%$ in wairakite and laumontite; and $75 \%$ in yugawaralite. It is to be noted that in all three last-mentioned zeolites the extraframework cation is $\mathrm{Ca}$, whose presence certainly favours order. All zeolites of class 2 always have a composition very near to the stoichiometric formula.

Acknowledgements. This work was supported by the Consiglio Nazionale delle Ricerche of Italy.

in hydrated chabazite. Natural and Na-, $\mathrm{Ca}-, \mathrm{Sr}-$ and $\mathrm{K}-$ exchanged chabazite. Zeolites 2, 303-309.

Bartl, H., 1970. Strukturverfeinerung von Leonhardit $\mathrm{Ca}\left(\mathrm{Al}_{2} \mathrm{Si}_{4} \mathrm{O}_{12}\right)$. $3 \mathrm{H}_{2} \mathrm{O}$, mittels Neutronen-Beugung. $\mathrm{N}$. Jb. Miner. Mh. 1970, 298-310.

Bartl, H., 1973. Neutronenbeugungsuntersuchung des Zeolithes Heulandit. Zeit. Krist. 137, 440-441.

Baur, W. H., 1964. On the cation and water positions in faujasite. Amer. Miner. 49, 697-704.

Baur, W. H., 1978. Variation of mean $\mathrm{Si}-\mathrm{O}$ bond lengths in silicon-oxygen tetrahedra. Acta Cryst. B34, 17511756.

Bennett, J. M. \& Smith, J. V., 1968. Positions of cations and molecules in zeolites with the faujasite type framework. I. Dehydrated Ca-exchanged faujasite. Mat. Res. Bull. 3, 633-642.

Breck, D. W., 1974. Zeolite molecular sieves, Wiley, New York.

Bresciani-Pahor, N.; Calligaris, M.; Nardin, G.; Randaccio, L.; Russo, E. \& Comin-Chiaramonti, P., 1980. Crystal structure of a natural and a partially silverexchanged heulandite. J. Chem. Soc. Dalton Trans. 1980, 1511-1514.

Fischer, K. \& Schramm, V., 1971. Crystal structure of a gismondite, a detailed refinement. Adv. Chem. Ser. 101, $250-258$.

Galli, E., 1971. Refinement of the crystal structure of stilbite. Acta Cryst. B27, 833-841.

Galli, E., 1975. Crystal structure refinement of mazzite. Rend. Soc. Ital. Miner. Petrol. 31, 599-612.

Galli, E., 1976. Crystal structure refinement of edingtonite. 
Acta Cryst. B32, 1623-1627.

Galli, E. \& Alberti, A., 1975a. The crystal structure of stellerite. Bull. Soc. Fr. Miner. Crist. 98, 11-18.

Galli, E. \& Alberti, A., 1975b. The crystal structure of barrerite. Bull. Soc. Fr. Miner. Crise. 98, 331-340.

Galli, E.; Gottardi, G. \& Pongiluppi, D., 1979. The crystal structure of the zeolite merlinoite. N. Jb. Miner. Mh 1979, 1-9.

Galli, E.; Passaglia, E. \& Zanazzi, P. F., 1982. Gmelinite: structural refinement of sodium-rich and calcium-rich natural crystals. N. Jb. Miner. Mh. 1982, 145-155.

Galli, E.; Gottardi, G.; Mayer, H.; Preisinger, A. \& Passaglia, E., 1983. The structure of potassium exchanged heulandite at 293, 373 and 593K. Acta Cryst. B39, 189-197.

Gard, J. A. \& Tait, J. M., 1972. The crystal structure of the zeolite offretite. Acta Cryst. B28, 825-834.

Gard, J. A. \& Tait, J. M., 1973. Refinement of the crystal structure of erionite. Molecular sieves (Uytterhoeven J. B. ed.), Leuven Univ. Press, 94-99.

Gottardi, G., 1978. Mineralogy and crystal chemistry of zeolites. Natural zeolites (Sand L. B. and Mumpton F. A. eds.), Pergamon, Oxford, 31-34.

Gottardi, G. \& Alberti, A., 1974. Domain structure in garronite: a hypothesis. Miner. Mag. 39, 898-899.

Gramlich, V., 1971. Untersuchung und Verfeinerung pseudosymmetrischer Strukturen. Diss. no. 4633 ETH, Zurich.

Hazen, R. M. \& Finger, L. W., 1979. Polyhedral tilting: a common type of pure displacive phase transition and its relationship to analcite at high pressure. Phase Transitions $1,1-22$.

Hesse, K. F., 1983. Refinement of a partially disordered natrolite. Zeit. Krist. 163, 67-74.

Jones, J. B., 1968. Al-O and $\mathrm{Si}-\mathrm{O}$ tetrahedral distances in aluminosilicate framework structures. Acta Cryst. B24, 355-358.

Kawahara, A. \& Curien, H., 1969. La structure cristalline de l'érionite. Bull. Soc. Fr. Miner. Crist. 92, 250-256.

Kerr, I. S. \& Williams, D. J., 1969. The crystal structure of yugawaralite. Acta Cryst. B25, 1183-1190.

Kocman, V.; Gait, R. I. \& Rucklidge, J., 1974. The crystal structure of bikitaite. Amer. Miner. 59, 71-78.

Koyama, K. \& Takéuchi, Y., 1977. Clinoptilolite: the distribution of potassium atoms and its role in thermal stability. Zeit. Krist. 145, 216-239.

Krogh Andersen, E.; Danø, M. \& Petersen. O. V., 1969. The mineralogy of Ilimaussaq. XIII. A tetragonal natrolite. Medd. om Grønland 181, no. 10, 1-19.

Kvick, A. \& Smith, J. V., 1983. A neutron diffraction study of the zeolite edingtonite. J. Chem. Phys. 79, 23562362.

Majer, V., 1953. Chabazite and stilbite from Bor. Spomenica Mise Kispatica (Zagreb) (Jugoslav. Akad. Zuan.
Umjet), 175-192 (in Serbo-Croatian).

Mazzi, F. \& Galli, E., 1978. Is each analcime different? Amer. Miner. 63, 448-460.

Mazzi, F. \& Galli, E., 1983. The tetrahedral framework of chabazite. N. Jb. Miner. Mh. 1983, 461-480.

Mazzi, F.; Galli, E. \& Gottardi, G., 1984. Structure refinements of two tetragonal edingtonites. N. Jb. Miner. Mh 1984, 373-382.

Merlino, S., 1984. Recent results in structural studies of zeolites and zeolite-like materials. Proc. 6th Int. Conf. Zeolites Bisio A. \& Olson D. H. eds., Butterworth, Guildford, pp 747-759.

Merlino, S.; Galli, E. \& Alberti, A., 1975. The crystal structure of levyne. Tscherm. Miner. Petr. Mitt. 22, 117-129.

Mortier, W. J.; Pluth, J. J. \& Smith, J. V., 1975. Positions of cations and molecules in zeolites with mordenite-type framework. I. Dehydrated Ca-exchanged ptilolite. Mat. Res. Bull. 10, 1037-1046.

Mortier, W. J.; Pluth, J. J.\& Smith, J. V., 1976a. Positions of cations and molecules in zeolites with mordenite-type framework. III. Rehydrated Ca-exchanged ptilolite. Mat. Res. Bull. 11, 15-22.

Mortier, W. J.; Pluth, J. J. \& Smith, J. V., 1976b. The crystal structure of dehydrated natural offretite with stacking faults of erionite type. Zeit. Krist. 143, 319-332.

Passaglia, E., 1970. The crystal chemistry of chabazites. Amer. Miner. 55, 1278-1301.

Peacor, D. R., 1973. High temperature, single-crystal X-ray study of natrolite. Amer. Miner. 58, 676-680.

Peacor, D. R.; Dunn, P. J.; Simmons, W. B.; Tillmanns, E. \& Fischer, R. X., 1984. Willhendersonite, a new zeolite isostructural with chabazite. Amer. Miner. 69, 186-189.

Pechar, F., 1981. An X-ray diffraction refinement of the structure of natural natrolite. Acta Cryst. B37, 19091911.

Pechar, F.; Schafer, W. \& Will, G., 1983. A neutron diffraction refinement of the crystal structure of natural natrolite. Zeit. Krist. 164, 19-24.

Perrotta, A. J., 1967. The crystal structure of epistilbite. Miner. Mag. 36, 480-490.

Perrotta, A. J. \& Smith, J. V., 1964. The crystal structure of brewsterite, $\mathrm{Ba}_{0.5} \mathrm{Sr}_{1.5} \mathrm{Al}_{4} \mathrm{Si}_{12} \mathrm{O}_{32} \cdot 10 \mathrm{H}_{2} \mathrm{O}$. Acta Cryst. 17, 857-862.

Rinaldi, R.; Pluth, J. J. \& Smith, J. V., 1974. Zeolites of the phillipsite family. Refinement of the crystal structure of phillipsite and harmotome. Acta Cryst. B30, 24262433.

Schlenker, J. L.; Pluth, J. J. \& Smith, J. V., 1977. Refinement of the crystal structure of brewsterite. Acta Cryst. B33, 2907-2910.

Slaughter, M., 1970. Crystal structure of stilbite. Amer. Miner. 55, 387-397. 
Smith, J. V.; Pluth, J. J.; Artioli, G. \& Ross, F. K., 1984. Neutron and X-ray refinements of scolecite Proc. 6th Int. Zeolite Conf. Bisio A. \& Olson D. H. eds., Butterworths, Guildford, pp 842-850.

Takéuchi, Y.; Mazzi, F.; Haga, N. \& Galli, E., 1979. The crystal structure of wairakite. Amer. Miner. 64, 9931001.

Tillmanns, E. \& Fischer, R., 1981. Crystal structure of a new zeolite mineral. Acta Cryst. A37 (supplement),
$\mathrm{C}-186$.

Vaughn, P. A., 1966. The crystal structure of the zeolite ferrierite. Acta Cryst. 21, 983-990.

Vezzalini, G., 1984. A refinement of Elba dachiardite: opposite acentric domains simulating a centric structure. Zeit. Krist. 166, 63-72.

Wise, W. S. \& Tschernich, R. W., 1978. Habits, crystal forms and composition of thomsonite. Canad. Miner. 16, 487-493. 